\title{
Electrospray Mass Spectrometry of Borane Salts: The Electrospray Needle as an Electrochemical Cell
}

\author{
Cornelis E. C. A. Hop, Dovas A. Saulys, and Donald F. Gaines \\ Department of Chemistry, University of Wisconsin-Madison, Madison, Wisconsin USA
}

Two borane salts $\left(\left[(\mathrm{Me})_{4} \mathrm{~N}\right]\left[\mathrm{B}_{3} \mathrm{H}_{8}\right]\right.$ and $\left.\mathrm{Cs}\left[\mathrm{B}_{3} \mathrm{H}_{8}\right]\right)$ were examined by electrospray mass spectrometry in the positive ion mode. Acetonitrile solutions provided the most informative spectra; the salts exhibited a remarkable degree of clustering under electrospray conditions, and virtually all signals corresponded to cationic cluster ions of the general formula ([cation $\left.\left.{ }^{m+}\right]_{x}\left[\text { anion }^{n-}\right]_{y}\right\}^{(m x-n y)+}$. In contrast, methanol solutions of these salts produced only $\mathrm{B}\left(\mathrm{OCH}_{3}\right)_{4}^{-}$cluster ions under otherwise identical conditions. ${ }^{11} \mathrm{~B}$ NMR analyses corroborate the identities of the methanol solution species that enter the electrospray source and the reaction product generated during the electrospray process. (J Am Soc Mass Spectrom 1995, 6 , $860-865)$

S cientists have long sought accurate and sensitive methods to determine the molecular weight of biopolymers such as proteins, carbohydrates, and oligonucleotides. Mass spectrometry has the potential to provide much more accurate values than traditional analytical techniques, provided the biopolymers can be transformed into gas-phase ions-until recently a seemingly insurmountable barrier. The recent development of electrospray ionization [1] however, has revolutionized the biochemical applications of mass spectrometry. The success of electrospray ionization for analysis of high molecular weight compounds relies on the very mild nature of the ionization process. For most biopolymers only the intact protonated molecules are observed and the influence of the solvent is usually limited to altering the charge state distribution. The electrospray process does not normally ionize the analytes directly; rather, it assists the transfer of ionic solution analytes into the gas phase. It has recently been shown that neutral, relatively nonpolar compounds can be analyzed with electrospray as well [2]. In the positive ion mode electrochemical oxidation at the metal-solution interface of the electrospray needle generates molecular radical cations from compounds such as alkyl-substituted metalloporphyrins, polycyclic aromatic hydrocarbons, and metallocenes [2]. In the negative ion mode reduction of compounds has been observed to produce molecular radical anions [2d]. Thus, single electron transfer reactions can occur under electrospray conditions. These

Address reprint requests to C. E. C. A. Hop, Department of Chemistry, University of Wisconsin-Madison, 1101 University Avenue, Madison, Wisconsin 53706. observed processes are consistent with the electrophoretic charge separation mechanism suggested for electrospray by Kebarle and co-workers [3].

Compared to electrospray mass spectrometric analysis of biochemical compounds, much less attention has been paid to analysis of inorganic compounds [4] To remedy this situation, we recently [5] demonstrated that electrospray mass spectrometry in the negative ion mode is a valuable technique for identification of borane salts, which cannot be analyzed with conventional mass spectrometric ionization methods such as electron impact ionization, chemical ionization, and liquid secondary ion mass spectrometry. Acetonitrile solutions provided very informative spectra: virtually all signals corresponded to anionic clusters of ions (henceforth called cluster ions) that have the general formula $\left\{\left[\text { cation }^{m+}\right]_{x}\left[\text { anion }^{n-}\right]_{y}\right\}^{(n y-m x)-}$. Herein, we report preliminary results to show that the nature of the solvent is a critical parameter in these experiments. With acetonitrile solutions spectra are obtained that are characteristic for the borane salts. In contrast, with the methanol solutions only reaction products are observed.

\section{Experimental}

A VG AutoSpec triple sector (EBE) mass spectrometer (VG Analytical Ltd., Manchester, UK) equipped with the Mark II electrospray source was operated in the negative or positive ion mode [6]. The Mark II electrospray source has larger orifices for the various skimmer cones, increased pumping capacity, and a hexapole focusing unit to improve sensitivity and ease of use. The distance between the needle and the counterelec- 
trode was usually $8-10 \mathrm{~mm}$. The accelerating voltage was $4000 \mathrm{~V}$ and the potentials on the needle, counterelectrode, and sampling cone were typically 8000, 5000, and $4000 \mathrm{~V}$, respectively. All experiments were performed with a resolution of 1250 (to obtain maximum signal strength) and a scan speed of $10 \mathrm{~s}$ per decade. The samples were dissolved in $\mathrm{CH}_{3} \mathrm{CN}, \mathrm{CH}_{3} \mathrm{OH}, \mathrm{H}_{2} \mathrm{O}$, or THF (200 ng $\mu \mathrm{L}^{-1}$ ) and the flow rate was $15 \mu \mathrm{L} \mathrm{min}{ }^{-1}$. Nitrogen was used as both the nebulizer gas $\left(16 \mathrm{~L} \mathrm{~h}^{-1}\right)$ and the bath gas $\left(60^{\circ} \mathrm{C} ; 400 \mathrm{~L} \mathrm{~h}^{-1}\right)$.

The borane salts examined, $\left[(\mathrm{Me})_{4} \mathrm{~N}\right]\left[\mathrm{B}_{3} \mathrm{H}_{8}\right]$ (I) and $\mathrm{Cs}\left[\mathrm{B}_{3} \mathrm{H}_{8}\right]$ (II), were from laboratory stocks. The high resolution ${ }^{1} \mathrm{H},{ }^{11} \mathrm{~B}$, and ${ }^{11} \mathrm{~B}\{\mathrm{H}\}$ NMR spectra of $\mathrm{CD}_{3} \mathrm{OD}$ and $\mathrm{CD}_{3} \mathrm{CN}$ solutions of these compounds showed only resonances attributable to the cations and/or anions. The NMR spectra were recorded with a Bruker AM-500 spectrometer (Bruker, Billerica, MA).

\section{Results and Discussion}

Figure 1 shows the positive ion mode electrospray mass spectra of $\mathrm{CH}_{3} \mathrm{CN}$ solutions of $\left[(\mathrm{Me})_{4} \mathrm{~N}\right]\left[\mathrm{B}_{3} \mathrm{H}_{8}\right]$ (I) and $\mathrm{Cs}\left[\mathrm{B}_{3} \mathrm{H}_{8}\right]$ (II). These spectra are compatible with those obtained in the negative ion mode [5]. The most remarkable feature of the spectra is the extensive clustering displayed by I and II under electrospray conditions. All signals correspond to cluster ions \{[cation $\left.\left.^{m+}\right]_{x}\left[\text { anion }^{n-}\right]_{y}\right\}^{(m x-n y)+}$. (All experiments were performed with a low sampling cone voltage. At a high sampling cone voltage the onset of multiply charged ions shifts to higher mass. Higher sampling cone voltages are known [7] to cause fragmentation of relatively weakly bound species, such as our cluster ions, by energetic collisions with background gas.) For example, for I the first doubly charged cluster ion is observed at $m / z 1049(x=19 ; y=17)$ [all the cluster ions are identified by their average mass-to-charge ratios, instead of their mass-to-charge ratio distribution $]^{1}$ and the first triply charged cluster ion is observed at $m / z 1488(x=40 ; y=37){ }^{2}$ The series of cluster ions that has an overall $4+$ charge commences at $m / z 2052(x=73 ; y=69){ }^{3}$ In contrast, the spectrum of II shows predominantly singly and doubly charged cluster ions. The first of the doubly charged cluster ions is observed at $m / z 1954(x=23 ; y=21){ }^{4}$ Thus, the onset of doubly charged cluster ions in terms of the number of $\mathrm{B}_{3} \mathrm{H}_{8}^{-}$units is similar for I and II. Note also that the onsets of the multiply charged cluster ions are similar in the positive and negative ion mode [5].

\footnotetext{
${ }^{1} m / 2991(x=18 ; y=16)$ could be the first doubly charged cluster ion, but its signal coincides with that of the $(x=9 ; y=8)$ ions.

$2 m / z 1450(x=39 ; y=36)$ could be the first triply charged cluster ion, but its signal coincides with that of the $(x=13 ; y=12)$ and $(x=26 ; y=24)$ ions.

${ }^{3} m / z 2023(x=72 ; y=68)$ could be the first quadruply charged cluster ion, but its signal coincides with that of the $(x=18 ; y=17)$, $(x=36 ; y=34)$, and $(x=54 ; y=51)$ ions.

${ }^{4} m / z 1867(x=22 ; y=20)$ could be the first doubly charged cluster ion, but its signal coincides with that of the $(x=11 ; y=10)$ ions.
}

The positive ion mode electrospray mass spectra of $\mathrm{CH}_{3} \mathrm{OH}$ solutions of I and II (Figure 2) differ substantially from those of the corresponding $\mathrm{CH}_{3} \mathrm{CN}$ solutions (Figure 1). In fact, examination of the mass spectra of the $\mathrm{CH}_{3} \mathrm{OH}$ solutions (Figure 2) indicates that electrospray of these $\mathrm{B}_{3} \mathrm{H}_{8}^{-}$salts does not yield any cluster ions that contain $B_{3}$ units. Degassing the solution with Ar prior to use did not change the spectra, which implies that the presence of residual $\mathrm{O}_{2}$ is irrelevant. To exclude the possibility of a reaction between $\mathrm{B}_{3} \mathrm{H}_{8}^{-}$ and $\mathrm{CH}_{3} \mathrm{OH}$ prior to electrospray ionization, the NMR spectra of the $\mathrm{CD}_{3} \mathrm{OD}$ solutions of I and II were recorded; they showed only the presence of $\left[(\mathrm{Me})_{4} \mathrm{~N}\right]\left[\mathrm{B}_{3} \mathrm{H}_{8}\right]$ and $\mathrm{Cs}\left[\mathrm{B}_{3} \mathrm{H}_{8}\right]$ in the solutions and did not change over time.

To elucidate the nature of the species generated from the $\mathrm{CH}_{3} \mathrm{OH}$ solutions, we obtained the NMR spectrum of an electrosprayed $\mathrm{CH}_{3} \mathrm{OH}$ solution of II ( $\mathrm{Cs}\left[\mathrm{B}_{3} \mathrm{H}_{8}\right]: 2000 \mathrm{ng} \mu \mathrm{L}^{-1}$ ). We removed the electrospray needle assembly from the source and collected the electrosprayed solution in a flask mounted around the needle. The charge on the needle was reduced from 4000 to $1000 \mathrm{~V}$ to prevent discharges. The flow rate was $15 \mu \mathrm{L} \mathrm{min} \operatorname{mos}^{-1}$ and $12.5 \mathrm{~mL}$ was sprayed and collected. The methanol was pumped away on a vacuum line and the residual white solid was dissolved in $\mathrm{CD}_{3} \mathrm{OD}$. The NMR spectrum of the latter solution (Figure 3 ) exhibits a resonance position that corresponds to the presence of $\mathrm{B}\left(\mathrm{OCH}_{3}\right)_{4}^{-}(37 \mathrm{~mol} \mathrm{\%})$ [8] as well as $\mathrm{B}_{3} \mathrm{H}_{8}^{-}(63 \mathrm{~mol} \%)$, and allows assignment of the signals observed in the electrospray mass spectra of the $\mathrm{CH}_{3} \mathrm{OH}$ solutions. For example, $m / z 283$ in the spectrum of the $\mathrm{CH}_{3} \mathrm{OH}$ solution of $\mathrm{I}$ corresponds to $\left[(\mathrm{Me})_{4} \mathrm{~N}\right]_{2}\left[\mathrm{~B}\left(\mathrm{OCH}_{3}\right)_{4}\right]_{1}^{+}$and $m / z 492$ corresponds to $\left[(\mathrm{Me})_{4} \mathrm{~N}\right]_{3}\left[\mathrm{~B}\left(\mathrm{OCH}_{3}\right)_{4}\right]_{2}^{+}$. The spectrum of the $\mathrm{CH}_{3} \mathrm{OH}$ solution of II is dominated by $m / z 133\left(\mathrm{Cs}^{+}\right)$, $m / z 297\left(\mathrm{Cs}_{2}\left[\mathrm{OCH}_{3}\right]^{+}\right), m / z 401\left(\mathrm{Cs}_{2}\left[\mathrm{~B}\left(\mathrm{OCH}_{3}\right)_{4}\right]^{+}\right)$, $m / z \quad 669\left(\mathrm{Cs}_{3}\left[\mathrm{~B}\left(\mathrm{OCH}_{3}\right)_{4}\right]_{2}^{+}\right)$, and $m / z \quad 937$ $\left(\mathrm{Cs}_{4}\left[\mathrm{~B}\left(\mathrm{OCH}_{3}\right)_{4}\right]_{3}^{+}\right)$. The insets in Figure 2 also show that the observed isotope patterns of these signals match the calculated patterns.

The almost complete methanolysis exhibited by I and II under electrospray conditions was unexpected and we can only speculate about the mechanism of the $\mathrm{B}_{3} \mathrm{H}_{8}^{-} \rightarrow \mathrm{B}\left(\mathrm{OCH}_{3}\right)_{4}^{-}$reaction, because no intermediates were observed. The $\mathrm{B}_{3} \mathrm{H}_{8}^{-}$anion is known to be exceptionally stable toward hydrolysis [9] and, although it is not considered totally inert to methanol, the original preparations of triborohydride salts involved recrystallization from this solvent [10]. Similarly, our NMR solutions of approximately unit molarity of I and II in $\mathrm{CD}_{3} \mathrm{OD}$ exhibited no signs of decomposition after several weeks at room temperature. Furthermore, the electrospray mass spectra obtained under identical conditions with acetonitrile, water, and tetrahydrofuran (THF) as the solvents exhibited no observable solvolysis. (The electrospray mass spectra of acetonitrile and tetrahydrofuran solutions of these $\mathrm{B}_{3} \mathrm{H}_{8}^{-}$ salts are similar. However, the spectra of the tetrahy- 

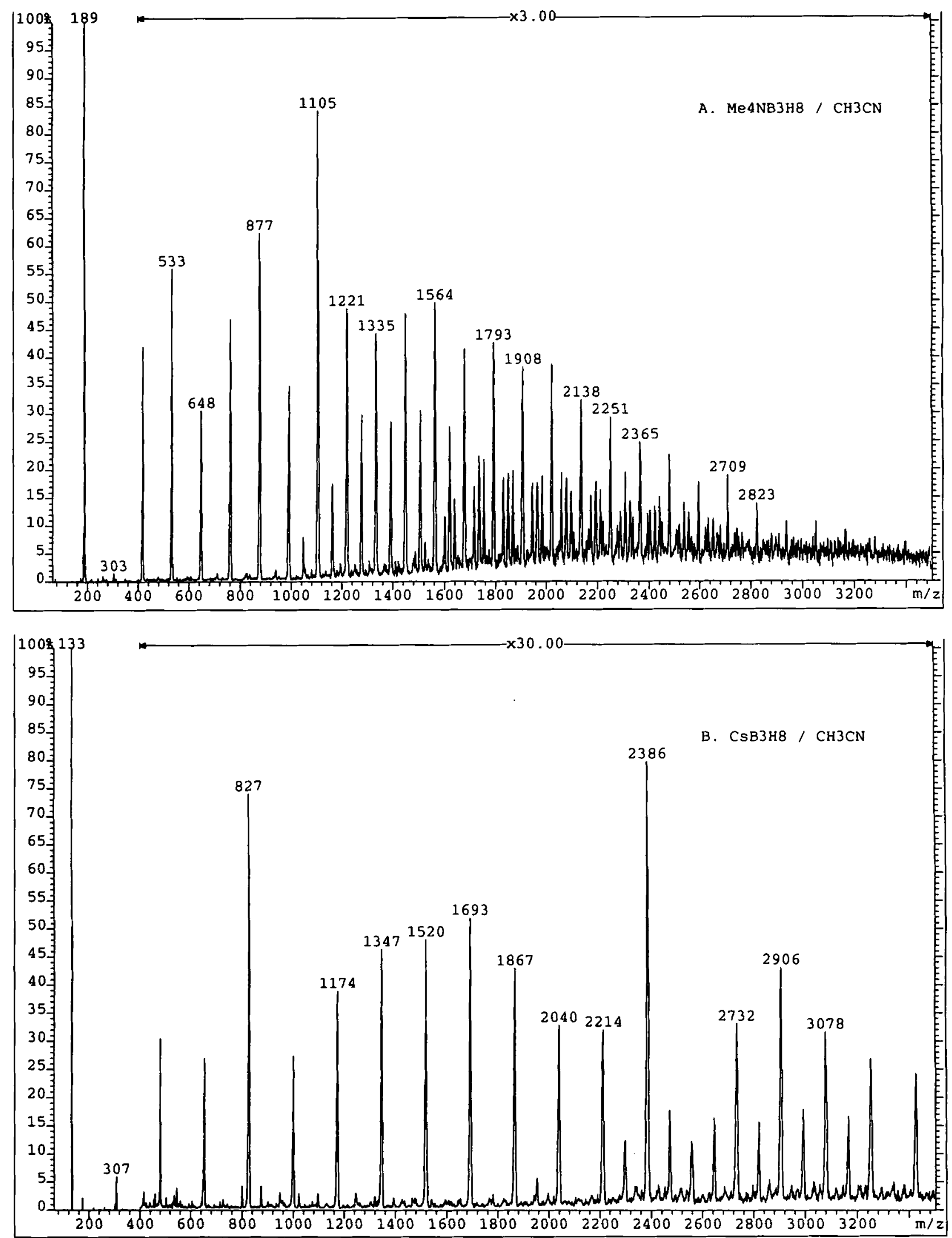

Figure 1. The positive ion mode electrospray mass spectra of $\mathrm{CH}_{3} \mathrm{CN}$ solutions of (a) $\left[(\mathrm{Me})_{4} \mathrm{~N}\right]\left[\mathrm{B}_{3} \mathrm{H}_{8}\right]$ and $(\mathrm{b}) \mathrm{Cs}\left[\mathrm{B}_{3} \mathrm{H}_{8}\right]$. 

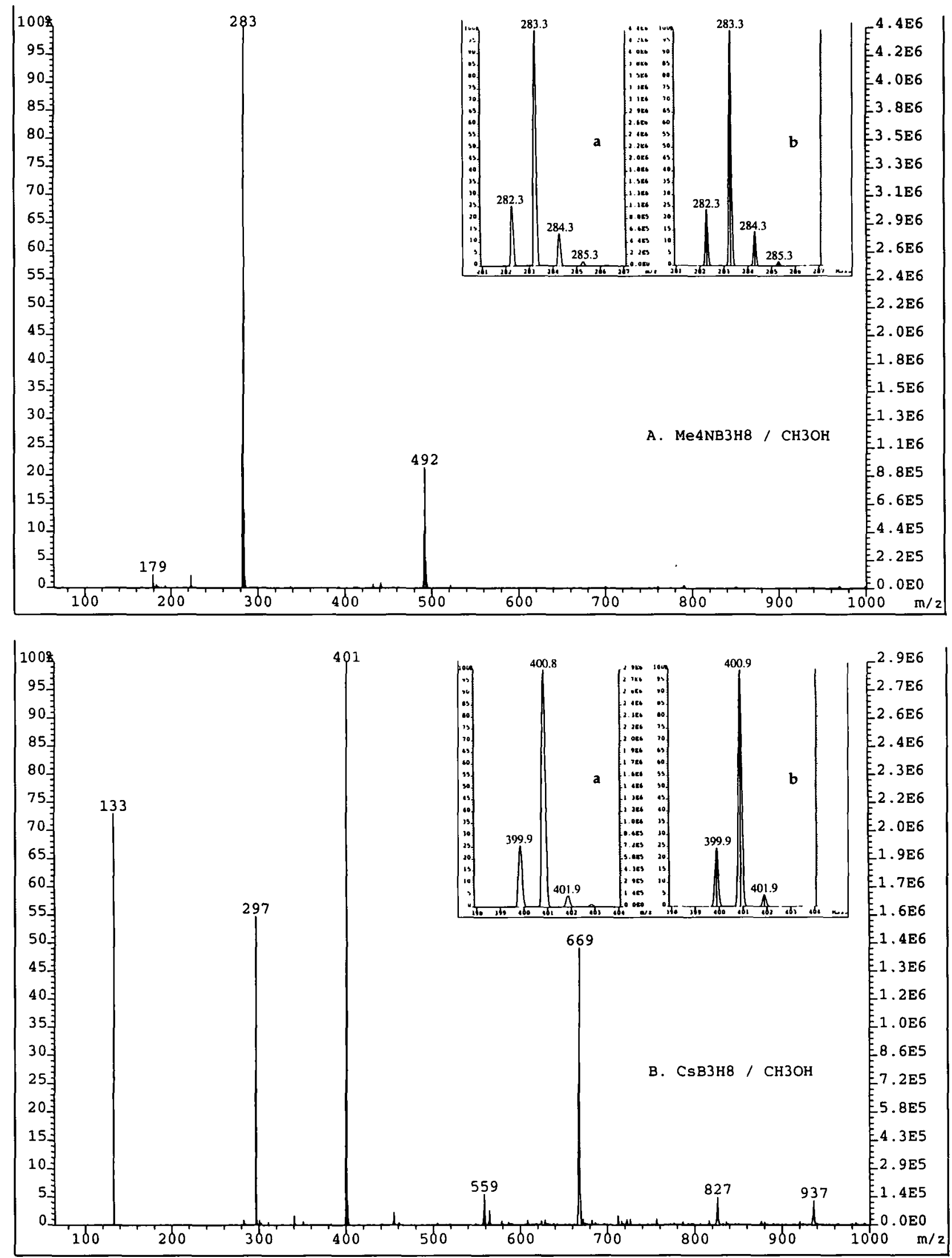

Figure 2. The positive ion mode electrospray mass spectra of $\mathrm{CH}_{3} \mathrm{OH}$ solutions of (a) [(Me) $\left.)_{4} \mathrm{~N}\right]\left[\mathrm{B}_{3} \mathrm{H}_{8}\right]$ and (b) $\mathrm{Cs}\left[\mathrm{B}_{3} \mathrm{H}_{8}\right]$. Insets: Experimental versus theoretical isotope patterns for (a) $\left[(\mathrm{Me})_{4} \mathrm{~N}\right]_{2}\left[\mathrm{~B}\left(\mathrm{OCH}_{3}\right)_{4}\right]_{1}^{+}$and (b) $\mathrm{Cs}_{2}\left[\mathrm{~B}\left(\mathrm{OCH}_{3}\right)_{4}\right]^{+}$. 


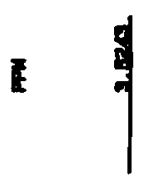

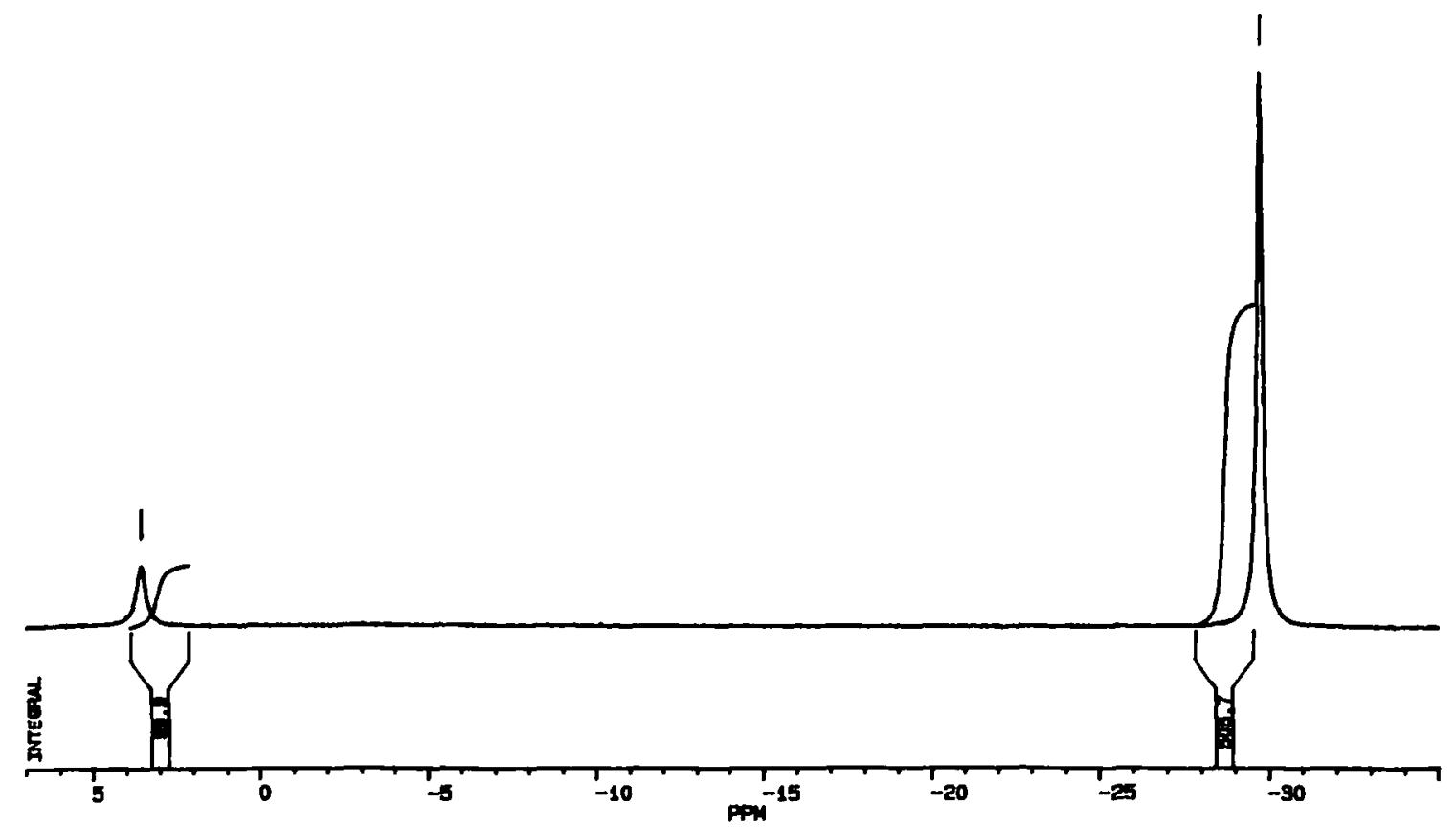

Figure 3. The $11 \mathrm{~B}\{1 \mathrm{H}\}$ NMR spectrum of an electrosprayed $\mathrm{CH}_{3} \mathrm{OH}$ solution of $\left[(\mathrm{Me})_{4} \mathrm{~N}\right]\left[\mathrm{B}_{3} \mathrm{H}_{8}\right]$. The downfield resonance $(\delta=3.52 \mathrm{ppm})$ is due to $\mathrm{B}\left(\mathrm{OCH}_{3}\right)_{4}^{-}$[8] and the upfield resonance $(\delta=-29.77 \mathrm{ppm})$ is due to $\mathrm{B}_{3} \mathrm{H}_{8}^{-}$.

drofuran solutions display less extensive clustering than those of the acetonitrile solutions. The spectra of the water solutions are rather weak and no cluster ions above $m / z 500$ were generated.) It is not obvious from a comparison of the chemical and physical properties of $\mathrm{CH}_{3} \mathrm{OH}, \mathrm{CH}_{3} \mathrm{CN}, \mathrm{H}_{2} \mathrm{O}$, and THF why only the former exhibits solvolysis, let alone to such a degree of completeness.

Gas phase basicities [11] [in kilocalories per mole: THF (190.7) $>\mathrm{CH}_{3} \mathrm{CN}$ (180.6) $>\mathrm{CH}_{3} \mathrm{OH}$ (174.1) > $\mathrm{H}_{2} \mathrm{O}(159.0)$ ] predict an order of reactivity which is not consistent with the observed results. Drago et al. have presented a six parameter equation to predict acid-base reaction enthalpies using $E, C \& T$ constants [12], but when the constants for the bases used here are applied to a typical hard acid, $\mathrm{B}(\mathrm{OR})_{3}$ [in kilocalories per mole: THF $(-4.17)>\mathrm{CH}_{3} \mathrm{CN}(-2.45)>\mathrm{CH}_{3} \mathrm{OH}$ $\left.(-2.35)>\mathrm{H}_{2} \mathrm{O}(-1.71)\right]$, or a borderline acid, $\mathrm{BEt}_{3}$ [THF $(-9.15)>\mathrm{CH}_{3} \mathrm{OH}(-5.25) \sim \mathrm{CH}_{3} \mathrm{CN}(-5.22)$ $\left.>\mathrm{H}_{2} \mathrm{O}(-4.41)\right]$, the resulting enthalpies are incompatible with our experimental data. On Gutmann's donicity scale [13], an experimental measure of nucleophilicity, the ranking approximates our results [in kilocalories per mole: THF (20) $>\mathrm{CH}_{3} \mathrm{OH}(19)>\mathrm{H}_{2} \mathrm{O}$ (18) $>\mathrm{CH}_{3} \mathrm{CN}$ (14)], but with a spread of values so narrow as to render them irrelevant. Clearly, differ- ences in nucleophilicity and/or basicity alone are insufficient to rationalize the observed pattern of reactivity; more specific aspects of the solvents must be invoked. Because the hydrogen atoms in the borane anions are negatively polarized with respect to the boron atoms, protic bases are capable not only of nucleophilic attack on boron, but also of concurrent elimination of dihydrogen, a pathway not available to aprotic reagents such as $\mathrm{CH}_{3} \mathrm{CN}$ and THF. Rationalizing the lack of reactivity of $\mathrm{CH}_{3} \mathrm{CN}$ and THF on these grounds, it remains only to differentiate the behavior of the water and methanol solutions.

Kebarle and co-workers [14] recently confirmed Smith's [15] description of the dependence of the electrospray onset voltage on the solvent surface tension; the former is proportional to the square root of the latter. Thus, the ratio of the onset voltages between water and methanol should be equal to the square root of the ratio of the surface tensions, $(72.8 / 22.6)^{1 / 2}=1.79$ (at $20{ }^{\circ} \mathrm{C}$ ), which implies that a significantly higher voltage may be required to observe solvolysis in aqueous solutions than in methanol.

For comparison, $\mathrm{B}_{12} \mathrm{H}_{12}^{2-}$ anions (from $\mathrm{Na}_{2}\left[\mathrm{~B}_{12} \mathrm{H}_{12}\right]$ ) did not react with $\mathrm{CH}_{3} \mathrm{OH}$ under identical electrospray conditions. This can probably be ascribed to the more inert nature of the closed cage $\mathrm{B}_{12} \mathrm{H}_{12}^{2-}$ anions. 
In conclusion, we have shown that electrospray mass spectrometry in the positive ion mode is a valuable technique for identification of borane salts as is the negative ion mode [5], provided that an inert solvent is used. For the $\mathrm{B}_{3} \mathrm{H}_{8}^{-}$salts investigated here, acetonitrile (an aprotic solvent) solutions provided the most informative spectra; virtually all signals correspond to cationic cluster ions. In the presence of neat methanol, a protic as well as nucleophilic solvent, the $\mathrm{B}_{3} \mathrm{H}_{8}^{-}$anions undergo solvolysis to $\mathrm{B}\left(\mathrm{OCH}_{3}\right)_{4}^{-}$ions during the electrospray ionization process with the needle voltage determining the degree of conversion. To our knowledge, this is the first example of a complex (electrochemical) reaction between the analyte and the solvent in electrospray mass spectrometry. Under certain conditions, therefore, it must be concluded that electrospray is not a mild ionization method.

\section{Acknowledgments}

The authors thank the University of Wisconsin Graduate Research Foundation and the National Science Foundation (CHE9304546, CHE-9305922, and DMR-9121074) for financial support and Dr. G. J. van Berkel for valuable discussions.

\section{References}

1. (a) Fenn, J. B.; Mann, M.; Meng, C. K.; Wong, S. F.; Whitehouse, C. M. Science 1989, 246, 64; (b) Smith, R. D.; Loo, J. A.; Emonds, C. G.; Baringa, C. J.; Udseth, H. R. Anal. Chem. 1990, 62, 882; (c) Mann, M. Org. Mass Spectrom. 1990, 25, 575; (d) Smith, R. D.; Loo, J. A.; Ogorzalek Loo, R. R.; Busman, M.; Udseth, H. R. Mass Spectrom. Rev. 1991, 10, 359.

2. (a) van Berkel, G. J.; McLuckey, S. A.; Glish, G. L. Anal. Chem. 1991, 63, 1098; (b) van Berkel, G. J.; McLuckey, S. A.; Glish,
G. L. Anal. Chem. 1992, 64, 1586; (c) Xu, X.; Nolan, S. P.; Cole, R. B. Anal. Chem. 1994, 66, 119; (d) Dupont, A.; Gisselbrecht, J.-P.; Leize, E.; Wagner, L.; Van Dorsselaer, A. Tetrahedron Lett. 1994, 35, 6083.

3. (a) Blades, A. T.; Ikonomou, M. G.; Kebarle, P. Anal. Chem. 1991, 63, 2109; (b) Kebarle, P.; Tang, L. Anal. Chem. 1993, 65, $972 \mathrm{~A}$.

4. (a) Katta, V.; Chowdhury, S. K.; Chait, B. T. J. Am. Chem. Soc. 1990, 112, 5348; (b) Colton, R.; Traeger, J. C. Inorg. Chim. Acta 1992, 201, 153; (c) Bond, A. M.; Colton, R.; Mah, Y. A.; Traeger, J. C. Inorg. Chem. 1994, 33, 2548 and references therein; (d) Lau, T.-C.; Wang, J.; Siu, K. W. M.; Guevremont, R. J. Chem. Soc., Chem. Commun. 1994, 1487; (e) Agnes, G. R.; Stewart, I. I.; Horlick, G. Appl. Spectrosc. 1994, 48, 1347; (f) Kane-Maguire, L. A. P.; Kanitz, R.; Sheil, M. M. J. Organomet. Chem. 1995, 486, 243 and references therein.

5. Hop, C. E. C. A.; Saulys, D. A.; Gaines, D. F. Inorg. Chem. 1995, 34, 1977.

6. Woolfitt, A. R.; Pugh, J.; Bott, P. A. Proceedings of the 42nd ASMS Conference on Mass Spectrometry and Allied Topics; Chicago, Illinois, May 29-June 3, 1994; p 759.

7. Hamdan, M.; Curcuruto, O. Rapid Commun. Mass Spectrom. 1994, 8, 274.

8. Nöth, H.; Wrackmeyer, B. Nuclear Magnetic Resonance Spectroscopy of Boron Compounds; Springer-Verlag: Berlin, 1978; p 136.

9. Shore, S. G. In Boron Hydride Chemistry; Muetterties, E. L., Ed.; Academic Press: New York, 1975; p 133.

10. Gaines, D. F.; Schaeffer, R.; Tebbe, F. Inorg. Chem. 1963, 2 , 526.

11. Lias, S. G.; Liebman, J. F.; Levin, R. D. J. Phys. Chem. Ref. Data 1984, 13, 695.

12. Drago, R. S.; Wong, N.; Ferris, D. C. J. Am. Chem. Soc. 1991, 113,1970 and references therein.

13. Gutmann, V. Coord. Chem. Rev. 1976, 18, 225.

14. Ikonomou, M. G.; Blades, A. T.; Kebarle, P. J. Am. Soc. Mass Spectrom. 1991, 2, 497.

15. Smith, D. P. H. IEEE Trans. Ind. Appl. 1986, IA-22, 527. 